Etikonomi

Volume 15 (2), October 2016

P-ISSN: 1412-8969; E-ISSN: 2461-0771

Page 85 - 96

\title{
GOOD CORPORATE GOVERNANCE IN MANUFACTURING COMPANIES TAX AVOIDANCE
}

\author{
Uun Sunarsih, Kartika Oktaviani \\ Sekolah Tinggi Ekonomi Indonesia \\ uun.sunarsih@yahoo.co.id, kartikaoktaviani31@gmail.com
}

\begin{abstract}
.
This study aimed to examine the effect of good corporate Governance against tax avoidance peroxided by the book tax gap and corporate governance is peroxided by institutional ownership, managerial ownership, independent board, audit committee and audit quality. This study was performed on companies listed on the Stock Exchange on the observation period 2011-2014. The method used is purposive sampling and obtained a sample of 10 companies. The data used is secondary data that can be downloaded through www.idx.co.id and www.sahamok.com. The results showed that the variables of the board of managerial ownership, independent directors, audit committee, and audit quality effect on tax avoidance while institutional ownership variable has no effect on tax avoidance. It is suspected that institutional ownership as a monitoring tool in any decision taken by the manager does not support an optimal oversight of management performance related to tax evasion.
\end{abstract}

Keywords: good corporate governance; tax avoidance; manufacturing companies

\begin{abstract}
Abstrak.
Penelitian ini bertujuan untuk menguji pengaruh good corporate governace terhadap tax avoidance yang diproksikan dengan book tax gap dan corporate governance diproksikan dengan kepemilikan institusional, kepemilikan manajerial, dewan komisaris independen, komite audit dan kualitas audit. Penelitian ini dilakukan pada perusahaan manufaktur yang terdaftar di BEI pada periode pengamatan 2011-2014. Metode penelitian yang digunakan adalah purposive sampling dan diperoleh sampel 10 perusahaan. Jenis data yang digunakan adalah data sekunder yang dapat diunduh melalui www.idx.co.id dan www.sahamok.com. Hasil penelitian menunjukkan bahwa variabel dewan kepemilikan manajerial, komisaris independen, komite audit, dan kualitas audit berpengaruh terhadap tax avoidance. Sedangkan variabel kepemilikan institusional tidak berpengaruh terhadap tax avoidance. Hal ini diduga bahwa kepemilikan institusional sebagai alat monitoring dalam setiap keputusan yang diambil oleh manajer tidak mampu mendorong peningkatan pengawasan yang lebih optimal terhadap kinerja manajemen terkait dengan penghindaran pajak.
\end{abstract}

Kata Kunci:tata kelola baik; penghindaran pajak; perusahaan manufaktur

First Draft: May 5, 2016; Revised: August 8, 2016; Approved: September 5, 2016 
Good Corporate Governance in Manufacturing Companies Tax Avoidance Uun Sunarsih, Kartika Oktaviani

\section{INTRODUCTION}

Tax planning is a business that is done taxpayer with the aim to reduce the number of tax burden so that the taxes paid will be lower. Minimizing the tax burden can be done in two ways, namely, from complying with the provisions of tax (legal) until the violation of the provisions of tax (illegal). According to some experts tax avoidance is an act to minimize the tax burden is still in the corridors of tax provision (legal), while in violation of tax provisions (illegal) is tax evasion.

Sari (2014) described in legal tax avoidance was not prohibited, although often get the spotlight that is less good than the tax office as having a negative connotation. Tax avoidance activity of late is expected to be the important things that must be considered by the tax authorities. The practice of tax evasion may lead to tax evasion efforts, this will certainly have negative effects for the country, because if allowed to continuously will cause the state to suffer loss of tax revenue by a significant amount.

Bappenas (2005) stated that the tax evasion phenomenon in Indonesia, in 2005 there were 750 Foreign Investment Company (PMA), which is considered tax evasion by reporting the loss within 5 years in a row and did not pay taxes. Based on tax data conveyed by the Director General of Taxes in 2012 there were 4,000 foreign companies which reported nil tax value, the company is known to experience a loss of over 7 years in a row. While DJP (2013) mentions tax avoidance is generally performed by companies engaged in the manufacturing and processing of raw materials (Prakosa, 2014).

Maharani and Suardana (2014) explains that the number of companies that tax evasion prove that corporate governance is not yet fully done up by public companies in Indonesia. Corporate governance is an issue that never go out to continue to be studied businessmen, academics, policy makers, and others. An understanding of corporate governance practices continue to evolve over time. Corporate governance is one interesting phenomenon to be studied in connection with the vigorous publicity about fraud as well as a business slump that occurred as a result of errors made by the executive management. 
Research related to tax avoidance has been widely implemented, such as is done by Annisa and Kurniasih (2012), Santoso (2014), and Fadhilah (2014). Corporate governance is proxied by the quality of auditors, audit committees, institutional ownership, board of commissioners, and independent board while tax avoidance is peroxided by the book tax gap. The difference results of these studies to examine the motivation to develop research that has been done Fadhilah (2014) by adding managerial ownership as a proxy of corporate governance.

Based on this background, the research questions are: fisrt,is the institutional ownership has an effect on tax avoidance? Second,is the managerial ownership affect the tax avoidance? Third,is the independent board effect on tax avoidance? Fourth,is the audit committee influence on tax avoidance? Fifth,is the quality of audits affect the tax avoidance?

This study aims to determine the effect of institutional ownership, managerial ownership, independent board, audit committee, the quality of audits of tax avoidance in the manufacturing companies listed in Indonesia Stock Exchange 2011-2014 period.

\section{METHOD}

This research is a quantitative study using secondary data obtained through www.idx.co.id and www.sahamok.com. The data used in this research is data that panel's annual report Manufacturing Company listed on the Indonesia Stock Exchange on the observation period 2011-2014.

The population in this study are all manufacturing companies listed in Indonesia Stock Exchange in the observation period 2011-2014. Selection of the sample using purposive sampling method, with the following characteristics: (1) Company listed on the Indonesia Stock Exchange 20112014 period. (2) Manufacturing companies that publish the complete annual financial statements are consistently the period 2011-2014. (3) Manufacturing companies that are not delisted during the observation period. (4) The financial statements using the Indonesian Rupiah. (5) Manufacturing company in from 2011 to 2014 do $n$ ot experience a loss before tax. (6) Book Value Tax 
Good Corporate Governance in Manufacturing Companies Tax Avoidance

Uun Sunarsih, Kartika Oktaviani

Gap (BTG) must be positive, because companies with negative BTG are a company that does not tax avoidance. Based on these criteria the sample used is 10 companies.

\section{Research Model}

To test the hypothesis then created a model that describes the relationship between variables to be studied. Models were prepared using a multiple regression equation as follows:

$$
\mathrm{BTG}=\alpha+\beta_{1} \mathrm{KI}+\beta_{2} \mathrm{KM}+\beta_{3} \mathrm{DKI}+\beta_{4} \mathrm{KA}+\beta_{5} \mathrm{AUDIT}+\varepsilon
$$

Where:

$$
\begin{array}{ll}
\text { BTG } & =\text { Book Tax Gap (peroxided tax avoidance) } \\
\text { KI } & =\text { Institutional Ownership } \\
\text { KM } & =\text { Managerial Ownership } \\
\text { DKI } & =\text { BOC Independent } \\
\text { KA } & =\text { Audit Committee } \\
\text { AUDIT } & =\text { Quality Audit }
\end{array}
$$

The model above is composed of: dependent variable that tax Avoidance, independent variables that institutional ownership, managerial ownership, independent board, audit committee, audit quality.

\section{Dependent Variables}

The dependent variable in this study is tax avoidance. The calculation of the variable tax avoidance has been widely used as a research study variables such as the Pohan (2008), Annisa and Kurniasih (2012), Fadhilah (2014), and Santoso (2014) using the formula: BTG = EBT-Taxable Income

\section{Independent variables}

Institutional Ownership (KI) is the number of shareholding by the institution. The indicator used to measure institutional ownership is the percentage of shares held by the institution of the entire number of shares outstanding. This variable was used as the study variables by Pohan (2008), Annisa and Kurniasih (2012) and Fadhilah (2014), using the formula: 
$K I=\frac{\sum \text { shares owned by institutional }}{\sum \text { shares outstanding }}$

Managerial Ownership (KM) is the level of ownership of shares owned by management and actively participates in the decision making of the company (director and commissioner). Indicators used to measure the managerial ownership are presences number of shares held by the managerial of the total shares outstanding. This variable was used as the study variables by Pohan (2008), using the formula:

$K M=\frac{\sum \text { shares owned by management }}{\sum \text { shares outstanding }}$

Independent Commissioner Board (DKI) is defined as the party that is not affiliated in any way with the controlling shareholder, has no affiliation with the directors or commissioners in internal and not served as a director of a company associated.

In this study board structure variable is peroxided by the percentage of the presence of independent board in a company. Variable has made the study variables by Pohan (2008), Annisa and Kurniasih (2012), Fadhilah (2014), Santoso (2014), and Puspita and Harto (2014) using the formula:

$D K I=\frac{\text { the number of independent board members }}{\text { the total number of commissioners }}$

Audit Committee (KA) serves to provide views on matters related to financial policies, accounting and internal control. The audit committee can be measured by the number of audit committee. This variable was used as the study variables by Pohan (2008), Annisa and Kurniasih (2012) and Fadhilah (2014), using the formula:

$$
\mathrm{KA}=\Sigma \text { The Audit Committee }
$$

Audit Quality is usually measured by the size of the size of the Public Accounting Firm (KAP), which conducted an audit in a company, if the company is audited by Public Accounting Firm (KAP) The Big Four, it will be more independent because it can withstand the pressures managers to report violations. 
Good Corporate Governance in Manufacturing Companies Tax Avoidance

Uun Sunarsih, Kartika Oktaviani

For this study companies audited by Public Accounting Firm (KAP) The Big Four namely Price Waterhouse Cooper (PWC), Deloitte, KPMG, Ernst \& Young (E \& Y) will be assigned a value of 1 , and if they are not audited by the four public accounting firm (KAP) under license KAP The Big Four will be rated 0. Quality audits on linear equations denoted by audit.

\section{DISCUSSION}

Classical Assumption Test Results

Test for normality in this test using the normal chart analysis of P-P Plot and Kolmogorov-Smirnov test with a significant level of 0.05 . Normality test results showed that the variables used in the regression model are normally distributed. Multicolinearity test is done by analysing the correlation between variables by using the calculation tolerance value and variance inflation factor (VIF). The test results showed no tolerance for independent variables that have a value tolerance of less than 0.10 . Therefore, it can be concluded that there is no multicollinearity between independent variables in the regression model.

Heteroscedasticity test is conducted by test glejser. Based on the test results glejser is that the significance probability value above 5\% confidence level. So we can conclude the regression model free from their heteroscedasticity. Autocorrelation test is conducted by test Durbin Waston (DW-Test). Based on test results are obtained autocorrecting value of Durbin Watson (DW) of 1.349. While the lower limit value (dl) of -2 and the upper limit value (du) of 2 . Thus obtained value DW is between the value and the value $\mathrm{du} \mathrm{dl}(\mathrm{dl} \leq \leq \mathrm{DW} \mathrm{du}$ ), so the result of the autocorrelation test are inconclusive for regression models were used.

Hypothesis testing

Based on test results obtained by the value of the coefficient of determination adjusted $\mathrm{R}^{2}$ of 0.874 (87.4\%). This means that $87.4 \%$ of the variation of tax avoidance can be explained by the institutional ownership, managerial ownership, independent board, audit committee, and audit quality 
while the remaining $12.6 \%$ is explained by other factors that are not included in this study.

Multiple linear analyses used to obtain the regression coefficients will determine whether the hypothesis made will be accepted or rejected. Then it is obtained the following equation:

$\mathrm{BTG}=15,404+0,081 \mathrm{KI}-23,274 \mathrm{KM}+4,967 \mathrm{DKI}+2,045 \mathrm{KA}+3,179 \mathrm{AUDIT}$

$\mathrm{t}$ test aims to determine whether the independent variable partially significant effect on the dependent variable and to further examine which of the independent variables that significantly influence tax avoidance. The test results of the research hypotheses by t test as follows:

Variable Institutional Ownership (KI) has a sign value 0.950 greater than 0.05. This indicates that the first hypothesis is rejected, which means that institutional ownership variable has no influence on tax avoidance. Variable Managerial Ownership (KM) has signed 0,000 less than 0.05. This indicates that the second hypothesis is accepted, in other words that managerial ownership variable effect on tax avoidance.

Meanwhile variable Independent Commissioner Board (DKI) has 0,001 significantly smaller than 0.05 . This suggests that the third hypothesis is accepted, that variable independent board has an influence on tax avoidance. Variable Audit Committee (KA) was obtained with significantly 0,000 less than 0.05. This suggests that the fourth hypothesis is accepted, that the audit committee variables had an influence on tax avoidance while the Audit Quality Variable obtained with significantly 0,000 less than 0.05 . This indicates that the fifth hypothesis is accepted, that the variable qualities of the audit have an impact on tax avoidance.

Effect of Institutional Ownership on Tax Avoidance

The first hypothesis states that institutional ownership negatively affects tax avoidance. The test results indicate that a significant level of 0.950 is greater than $\alpha=0.05$. So these results indicate that the first hypothesis which states that institutional ownership negatively affect tax avoidance rejected. These results 
Good Corporate Governance in Manufacturing Companies Tax Avoidance

Uun Sunarsih, Kartika Oktaviani

indicate that the presence of institutional ownership cannot be used as a monitoring tool in every decision taken by managers in order to support an optimal oversight of management performance. The results of this study support research and Kurniasih Annisa (2012) and Fadhilah (2014) which states that institutional ownership a positive effect on tax avoidance.

Effect of Managerial Ownership on Tax Avoidance

The second hypothesis states that managerial ownership negative effect on tax avoidance. The test results showed that the significant value of 0.000. Significant value less than 0.05 indicates that the second hypothesis which states that managerial ownership negative effect on tax avoidance accepted. These results indicate that managerial ownership variable able to improve oversight of a more optimal and may influence the management in making tax avoidance policy.

The results are consistent with the results of research conducted by Pohan (2008) who found managerial ownership negative effect on tax evasion. Research Pohan (2008) proved that the greater the concentration of ownership of shares by executives, the smaller the possibility of tax avoidance.

Effect of Independent Commissioner Board of the Tax Avoidance

The third hypothesis states that the independent board negative effect on tax avoidance. The test results showed that the significant value of 0.001 . Significant value less than 0.05 indicates that the third hypothesis which states that the board of commissioners negatively affect tax avoidance accepted. These results indicate that the proportion of independent board within companies to reduce tax evasion action, perhaps this is due to the greater or higher independent board, the more effective their performance in monitoring and controlling the performance of the directors or managers in the management of the company.

The results of this study contradict the results of research conducted by Pohan (2008) who found that the independent board positive effect on tax evasion and support the results of research conducted by Annisa and Kurniasih (2012), 
Fadhilah (2014), and Puspita and Harto (2014) which states independent board negative effect on tax avoidance.

Effect of Audit Committee on Tax Avoidance

The fourth hypothesis states that the audit committee negative effect on tax avoidance. The test results demonstrate the significant value of 0.000 less than 0.05 indicates that the fourth hypothesis which states that the audit committee negatively affect unacceptable tax avoidance. The results of this study indicate that the audit committee is able to improve oversight of management on tax evasion. The results of this study contradict the results of research conducted by Annisa and Kurniasih (2012) and Fadhilah (2014) who in his research found that the positive effect on the audit committee of tax avoidance.

Effect of Quality Audits of Tax Avoidance

The fifth hypothesis states that audit quality negatively affects tax avoidance. The test results showed that the significant value of 0.000 less than 0.05 indicates that the fifth hypothesis which states that the negative effect on the audit committee received tax avoidance. These results indicate that the audit would be used of KAP the Big Four have the possibility that management does not tax evasion. The results of this study contradict the results of research conducted by Annisa and Kurniasih (2012) who found that audit quality has positive influence on tax evasion. However, these results support the research conducted by Fadhilah (2014) who found that audit quality negatively affects tax avoidance.

\section{CONCLUSION}

The results of this study concluded that institutional ownership has no effect on tax avoidance. Institutional ownership as a monitoring tool in any decision taken by the manager allegedly did not support an optimal oversight of management performance related to tax evasion. While managerial ownership has a negative effect on tax avoidance. It is presumed that managerial ownership can improve more optimal control and may affect the management not to commit tax 
Good Corporate Governance in Manufacturing Companies Tax Avoidance Uun Sunarsih, Kartika Oktaviani

evasion. Variable independent board is to have a negative effect on tax avoidance. These results indicate that the proportion of independent board within the company could be expected to decrease tax avoidance, perhaps this is due to the greater or high commissioner who came from outside the company more effectively their performance in monitoring and controlling management performance.

The audit committee has a negative effect on tax avoidance. These results indicate that the audit committee could be expected to decrease tax avoidance, with such a large or small number of audit committee is able to improve supervision of the management, so that no tax avoidance. Audit quality has an influence on tax avoidance. These results indicate that the use of audit services The Big Four accounting firm that there is the possibility of management can reduce tax avoidance measures.

\section{REFERENCES}

Agusti, W.Y. (2014). Pengaruh Profitabilitas, Leverage, dan Corporate Governance terhadap Tax Avoidance (Studi Empiris Pada Perusahaan Manufaktur yang Terdaftar di BEI tahun 2009-2012). Jurnal Ekonomi. Vol 2, No. 3: 201-210.

Anggraini, F. R. R. (2006). Pengungkapan Informasi Sosial dan Faktor-Faktor yang Mempengaruhi Pengungkapan Informasi Sosial dalam Laporan Keuangan Tahunan (Studi Empiris pada Perusahaan-Perusahaan yang terdaftar Bursa Efek Jakarta). Simposium Nasional Akuntansi XI :23-26.

Annisa, N. A. \& L. Kurniasih. (2012). Pengaruh Corporate Governance terhadap Tax Avoidance. Jurnal Akuntansi dan Auditing. Vol. 8, No. 2: 95-189.

Coller, P. \& A. Gregory. (1999). Audit Committee Activity and Agency Cost. Journal of Accounting and Public Policy. Vol. 18 (4): 311-332.

Desai, M. A. \& D. Dharmapala. (2007). Corporate Tax Avoidance and Firm Value.Journal of Financial Economics. Vol. 21 (1): 51-60. 
Fadhilah, R. (2014). Pengaruh Good Corporate Governance terhadap Tax Avoidance (Studi Empiris Pada Perusahaan Manufaktur yang Terdaftar di BEI 2009-2011). Jurnal Ekonomi. Vol. 2 (2): 111-124.

Hanlon, M. \&S. Heitzman. (2010). A Review of Tax Research. Journal of Accounting and Economics. Vol. 50: 127-178.

Haruman, T. (2008). Pengaruh Struktur Kepemilikan terhadap Keputusan Keuangan dan Nilai Perusahaan: Survey pada Perusahaan Manufaktur di Bursa Efek Indonesia. Simposium Nasional Akuntansi XI.

Kay, J. A. (1980). The Anatomy of Tax Avoidance. In Income Distribution: The Limits to Redistribution. Proceedings of the 31st Symposium of the Colston Research Society, University of Bristol: 135-148.

KNKG (Komite Nasional Kebijakan Governance). (2006). Pedoman Umum Good Corporate Governance Indonesia. www.bapepam.go.id.

Maharani, I. G. A. C. \& K. A. Suardana. (2014). Pengaruh Corporate Governance, Profitabilitas, dan Karakteristik Eksekutif pada Tax Avoidance Perusahaan Manufaktur. Jurnal Akuntansi. Vol. 9 (2): 525539.

Prakosa, K.B. (2014). Pengaruh Profitabilitas, Kepemilikan Keluarga dan Corporate Governance Terhadap Penghindaran Pajak Di Indonesia. Simposium Nasional Akuntansi 17.

Puspita, S.R.\& P. Harto. (2014). Pengaruh Tata Kelola Perusahaan terhadap Penghindaran Pajak. Diponegoro Journal of Accounting, Volume 3, Nomor 2: $1-13$.

Sari, G.M. (2014). Pengaruh Corporate Governance, Ukuran Perusahaan, Kompensasi Rugi Fiskal dan Struktur Kepemilikan terhadap Tax Avoidance (Studi Empiris Pada Perusahaan Manufaktur yang Terdaftar di BEI tahun 2008-2012). Jurnal Ekonomi. Vol. 2 (3): 211220.

Shleifer, A.\&R. Vishney. (1986). Large Shareholders and Corporate Control. Journal of Political Economy. Vol. 94: 461-488. 
Good Corporate Governance in Manufacturing Companies Tax Avoidance Uun Sunarsih, Kartika Oktaviani

Winata, F. (2014). Pengaruh Corporate Governance terhadap Tax Avoidance Pada Perusahaan yang Terdaftar di Bursa Efek Indonesia tahun 2013. Tax \& Accounting Review, Vol. 4 (1): 71-80. 